\title{
THE INFLUENCE OF OWNERSHIP AND USING OF PC ON THE ATTITUDES TOWARD GEOGRAPHY
}

\author{
Milan Kubiatko, Katerina Mrazkova \\ Masaryk University, Czech Republic \\ E-mail: mkubiatko@gmail.com, mrazkovak@gmail.com
}

\begin{abstract}
The influence of information and communication technologies (ICT) is investigated in the present days on the attitudes toward different school subject by the relatively high number if investigators in the whole world. The research is focused on the finding of the influence of the ownership of ICT and using of ICT on the attitudes toward geography. The sample size was created by 351 czech lower secondary school pupils. The research tool was questionnaire, where demographic variables were ownership of PC, ownership of internet, gender, residence and class of pupils. Last demographic variable was how often pupils use ICT in the geography lessons. The attitudinal part was created by 23 5-point Likert type items. The reliability was determined by the using of Cronbach's alpha coefficient. The construct validity was determined by the using of exploratory factor analysis. From the next analysis was used analysis of variance to find out the influence of using and ownership of ICT on the attitudes toward geography.
\end{abstract}

Key words: attitudes toward geography, information and communication technologies, lower secondary school pupils, questionnaire.

\section{Introduction}

Nowadays, the information and communication technologies (ICT) play the important role in the education process. The application of ICT into learning process is different in individual school subjects. In some subjects is the application of ICT on the high level (technical subjects), but in some subjects it is on low level (humanistic subjects). In the centre of our investigation is the application of ICT into science subjects, concretely into geography. Geography is included among science subjects in the educational conditions of the Czech Republic.

However, the research studies focused on the level of ICT using in the geography lesson are very hard to find. About the positive effect of ICT on the geography teaching and learning is possible to find on the work of Rich, Robinson and Bednarz (2000). According to the authors the effect of ICT lies for example in the haring between students and between staff, and in developing teaching resources, creating learning-resources databases, and delivering courses. The majority of work is focused on the application and perception of geographical information system in the geography lessons and their effect on the perception of geography and achievement of students in the geography lessons. Some authors suggest that using geoinformation technologies in geography teaching improves the motivation of students. For example, Baker and White (2003) claim that the use of collaborative GIS has great potential for moving students quickly beyond practicing mapping where things occur into determining why things occur there. This type of activity, which is one of the aims of many standards, appears to be improved through the use of geoinformation technologies. One of work (Demirci, 2008) was regarding to application of GIS into geography lessons. Author used experimental method and found out, after implementation 
PROBLEMS

OF EDUCATION

IN THE $21^{\text {st }}$ CENTURY

Volume 50, 2012

of GIS into geography lessons, the higher success of students in the geography. GIS has the ability to store, retrieve, manipulate and analyse a wide range of spatially-related data in order to produce maps. With GIS the user may ask questions of the data related to the map, search for patterns and distributions and investigate the underlying relationships between different sets of data. A computer-based GIS handles data quickly and efficiently, providing mapping facilities that would take a person many hours or even days to complete by hand. Although there are signs that GIS technology is beginning to be found in the field of geography at all educational levels, there is still some way to go before it is an accepted and integral part of teachers' pedagogy (Kerski, 2001; Lemberg and Stoltman, 1999; West, 1999). Taylor and Group (2003) quoted, pupils developed spatial awareness and decision-making skills and found using GIS software to produce and manipulate maps at a range of scales saved lesson time and gave better quality results. The internet increased access to authentic geographical data and information sources. ICT also allowed teachers to engage and motivate pupils about geographical concepts to a greater degree.

From the condition of Czech Republic was published study of Hubelova (2010), the authors found out rarely using of ICT in the geography lessons, if teachers used ICT, it was only as a source of information, usually copied to the exercise books and merely passively received by the pupils. Another type of situations analyzed was use of a teaching software program as a source of tasks. The pupils followed guidelines of the teacher who instructed them how to resolve the tasks. The method was the analyzing of the video recordings and the interesting fact is, that teachers did not use ICT more than 2 minutes in the lessons in the average. Other studies were focused on the influence of ICT on the geography curriculum. For example Morgan and Tidmarsh (2004) concerned with the ways in which ICT is conceptualized in geography education in England. The authors described the successfulness of the one project, where the ICT played important role. Some studies are focused on the attitudes toward ICT using in geography lessons, for example Kubiatko et al. (2010) found out the positive perception of ICT using in the lessons of science subjects, where the geography is also belonging. On the basis of the presented information it is possible to wait the positive effect of ICT on the perception of geography lessons.

From the previous part of the text is obvious, the ICT has got the positive effect on the attitudes toward geography as a school subject. However, in the Introduction part is possible to observe two interesting facts. First, the majority of research is focusing only on the effect of GIS not only on the attitudes toward geography, but also on the achievement in this subject. The effect of different tools of ICT is missing. The second fact is, in the conditions of Czech Republic are missing investigations focused on this kind of research. If they are published, they are unfortunately missing. So, in this study is the effort to add some results in the both gaps.

\section{Methodology of Research}

The study has got two main aims. The first was to find out the influence of the ownership of PC on the attitudes toward geography. The second one was to find out the influence of using of ICT on the attitudes toward geography. From the aim of the study the research questions were formulated:

1. Has got the ownership of the PC the influence on the attitudes toward geography?

2. Is there any relationship between the frequency of ICT using on the geography lessons and the attitudes toward geography? 


\section{Sample}

The sample size was created by the 351 Czech lower secondary school pupils. There were all grades of lower secondary education in Czech Republic. Lower secondary education in the Czech republic take four school years, after the finishing of it, the pupil can continue to some kind of high school. The average age was $13.03(\mathrm{SD}=1.24)$. The number of respondents with the own PC was 324; the rest was created by non-owners of PC. The frequency of using the ICT in the geography lessons was divided into three categories: 1 . Once a month $(n=204)$; 2. One a week $(\mathrm{n}=95) ; 3$. Never $(\mathrm{n}=52)$.

\section{Instrument}

The instrument was the questionnaire of own construction, which was divided into two basic parts. The first part included demographic variables like gender, residence, year of study, age, ownership of PC and the frequency of ICT using on the geography lessons. For the purpose of this text were used only last two variables. The second part contained 23 5-point Likert type items regarding to attitudes toward geography. The items were divided into four categories (see chapter Analyze of data). The items in positive meaning $(n=11)$ were coded following: 1 - totally disagree; 2 - slightly disagree; 3 - neutral; 4 - slightly agree; 5 - totally agree. The items in negative meaning $(\mathrm{n}=11)$ were coded reversely. If the average score was in interval $<2.75 ; 3.25>$ it is possible to say about neutral attitudes toward geography. If the score is higher than 3.25 it is possible to say about positive attitudes and if the score is lower than 2.75 , it is possible to say about negative attitudes. The construct validity of the questionnaire was set by explorative factor analysis (see chapter Analyze of data).

\section{Administration of the Instrument}

The instrument was distributed into 8 Czech lower secondary schools. All schools were chosen randomly. The administrators were teachers, whose were informed about the work with questionnaires. The pupils were assured about anonymity of the questionnaire. There was no time limit for the filling out the questionnaires, but the filling of questionnaires taking maximally 15 minutes.

\section{Data Analysis}

After the coding of answers into numbers the reliability of the instrument was determined. The value of Cronbach's alpha coefficient $(\alpha=0.89)$ indicated high reliability of the questionnaire.

The data were consequently interrogated to exploratory factor analysis with Varimax rotation. Before factor analysis were used the tests allowing the using of factor analysis. The value of KMO test was 0.91 and value of Bartlett test of sphericity was $\chi^{2}=2603.17(\mathrm{p}<$ 0.001). Both values indicated the suitability of the factor analysis using. The factor analysis divided items into four dimensions: 1. Geography as a school subject (11 items); 2. Geography in everyday life (3 items); 3. Map use in geography (3 items); 4. Geography in practice (3 items). The critical value of factor score was 0.40 , three items with value lower than 0.40 or with the value of factor score higher than 0.40 loaded in more than one category were excluded from the next analyses. The values of factor score are showed in the Table 1. 
PROBLEMS

OF EDUCATION

IN THE $21^{\text {st }}$ CENTURY

Volume 50, 2012

26

Table 1. Values of factor score.

\begin{tabular}{|c|c|c|c|c|}
\hline & Factor I & Factor II & Factor III & Factor IV \\
\hline \multicolumn{5}{|l|}{ I Geography as a school subject } \\
\hline 2. I am looking forward to the geography lessons. & 0.66 & 0.24 & 0.23 & 0.17 \\
\hline 4. Geography is my nightmare. & 0.42 & 0.06 & -0.12 & 0.38 \\
\hline 5. I do not consider most of the geography curriculum important. & 0.59 & 0.20 & 0.21 & 0.19 \\
\hline 7. Geography lessons are boring me. & 0.56 & 0.18 & 0.25 & 0.36 \\
\hline 9. Geography curriculum is difficult and I do not understand it. & 0.47 & 0.11 & -0.08 & 0.31 \\
\hline $\begin{array}{l}\text { 10. I would like geography lessons more if we had another } \\
\text { teacher. }\end{array}$ & 0.72 & 0.09 & 0.07 & -0.10 \\
\hline $\begin{array}{l}\text { 12. I do not understand how geography could be interesting for } \\
\text { someone. }\end{array}$ & 0.64 & 0.13 & 0.09 & 0.33 \\
\hline $\begin{array}{l}\text { 14. We have to memorize a lot of things in geography, e.g. } \\
\text { names of states and its capitals. }\end{array}$ & 0.67 & 0.05 & 0.22 & -0.02 \\
\hline 17. Geography lessons are a waste of time for me. & 0.58 & 0.25 & 0.16 & 0.39 \\
\hline $\begin{array}{l}\text { 21. I do not consider geography as an important and useful } \\
\text { subject. }\end{array}$ & 0.63 & 0.27 & 0.14 & 0.23 \\
\hline 23. If it were not for geography, I would like the school more. & 0.57 & 0.20 & 0.10 & 0.35 \\
\hline \multicolumn{5}{|l|}{ II. Geography in everyday life } \\
\hline $\begin{array}{l}\text { 8. I think that geography curriculum is important for science as } \\
\text { well as for the politics. }\end{array}$ & 0.01 & 0.66 & 0.03 & 0.28 \\
\hline 13. I am interested in the world that surrounds me. & 0.23 & 0.43 & 0.17 & 0.18 \\
\hline $\begin{array}{l}\text { 16. Geography enables learning about exotic countries which } \\
\text { would not possibly have the occasion to visit. }\end{array}$ & 0.39 & 0.61 & -0.04 & -0.06 \\
\hline \multicolumn{5}{|l|}{ III. Map use in geography } \\
\hline $\begin{array}{l}\text { 6. I would like to try map orientation in practice, outside the } \\
\text { class. }\end{array}$ & 0.35 & 0.01 & 0.60 & -0.04 \\
\hline 15. I avoid working with maps. & 0.28 & -0.07 & 0.50 & 0.36 \\
\hline $\begin{array}{l}\text { 18. Everybody should be able to use the map. } \\
\text { IV. Geography in practice }\end{array}$ & 0.11 & -0.03 & 0.68 & 0.28 \\
\hline $\begin{array}{l}\text { 11. Due to the geography lessons I understand better world } \\
\text { political affairs. }\end{array}$ & 0.15 & 0.11 & 0.00 & 0.66 \\
\hline $\begin{array}{l}\text { 20. I think that the necessary part of geography is learning } \\
\text { about the international cuisine, such as the Japanese sushi. }\end{array}$ & -0.03 & -0.08 & 0.36 & 0.55 \\
\hline $\begin{array}{l}\text { 22. Geography helps me to understand natural phenomenon, } \\
\text { e.g. what makes a rainbow. }\end{array}$ & 0.15 & 0.26 & 0.17 & 0.51 \\
\hline Eigenvalue & 7.21 & 1.45 & 1.27 & 1.21 \\
\hline$\%$ of variance & 31.33 & 6.32 & 5.51 & 5.27 \\
\hline \multicolumn{5}{|l|}{ Deleted items } \\
\hline $\begin{array}{l}\text { 1. I like geography because it enables learning about everyday } \\
\text { life of people from faraway countries. }\end{array}$ & 0.49 & 0.48 & 0.17 & 0.23 \\
\hline 3. Using geography textbooks is useless. & 0.04 & 0.03 & -0.07 & 0.07 \\
\hline $\begin{array}{l}\text { 19. What I learn in geography lessons, I can use in everyday } \\
\text { life. }\end{array}$ & 0.13 & 0.31 & 0.38 & 0.51 \\
\hline
\end{tabular}

Numbers of items are identical with numbers in questionnaire 
The analysis of covariance (ANCOVA) was used for the finding out the influence of the $\mid$\begin{tabular}{l} 
PROBLEMS \\
OF EDUCATION \\
IN THE 21 $1^{\text {st }}$ CENTURY \\
Volume 50, 2012 \\
\hline 27
\end{tabular} PC ownership and ICT using on the attitudes toward geography. The age was as covariate.

\section{Results of Research}

The mean score was $3.55(\mathrm{SD}=0.69)$, what indicated the relatively positive attitudes toward geography. However the aim of the study was to find out the influence of independent variables on the attitudes toward geography. The age had got the significant effect $(\mathrm{F}=34.72$; $\mathrm{p}<0.001)$. The ownership of PC had not got the statistically significant influence $(\mathrm{F}=0.11$; $\mathrm{p}=0.74)$. The PC owners achieved higher score $(\mathrm{x}=3.50 ; \mathrm{SD}=0.04)$ in comparison with non-owners $(\mathrm{x}=3.46$; $\mathrm{SD}=0.13)$. The effect of using of OCT on the geography lessons was significant $(\mathrm{F}=5.84 ; \mathrm{p}<0.01)$. The highest score achieved pupils, who used ICT on the geography lessons once a month $(\mathrm{x}=3.67$; $\mathrm{SD}=0.09)$, the lowest score achieved pupils, who never used ICT on the geography lessons $(\mathrm{x}=3.36$; $\mathrm{SD}=0.13)$ (figure 1$)$. The application of Tukey post-hoc test showed the significant difference between the groups "once a month" and "once a week" $(\mathrm{p}<0.05)$.

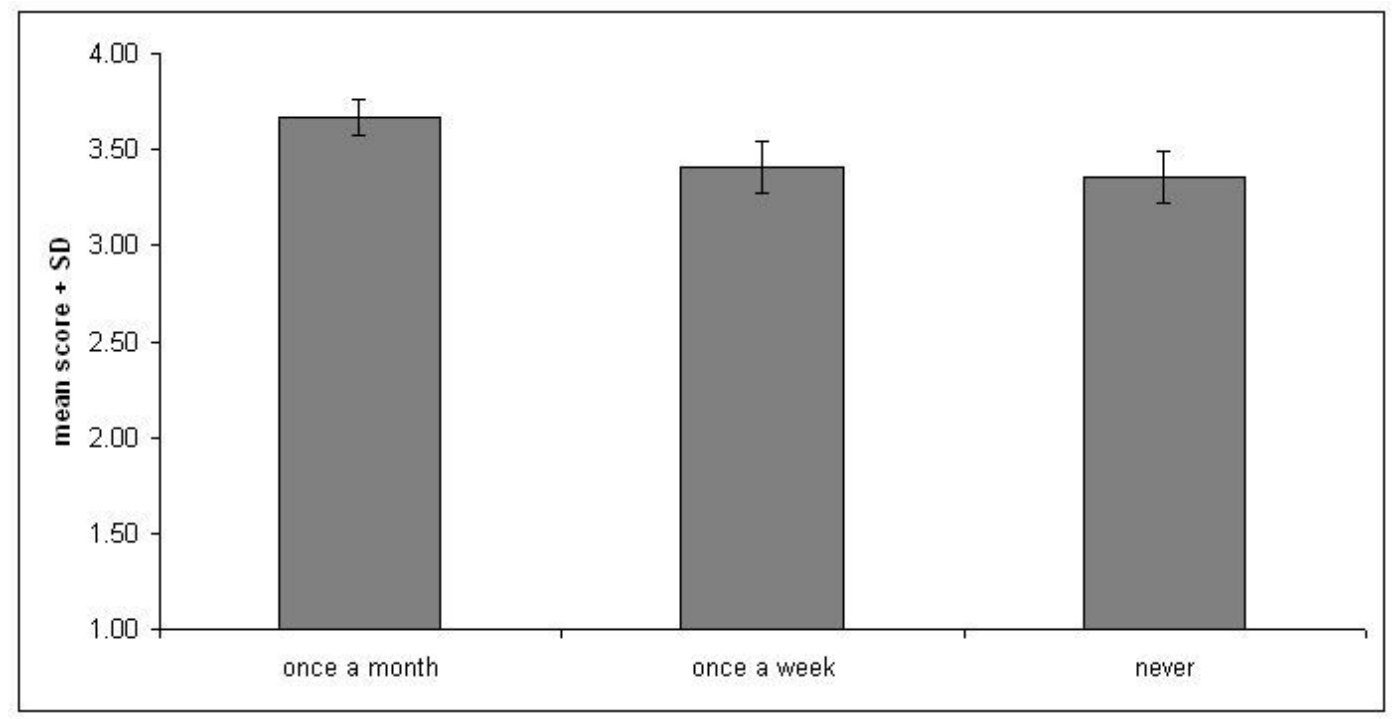

\section{Figure 1: The attitudes toward geography with the respect to ICT use on the geography lessons.}

Next, there is presented the influence of independent variables on the categories. The influence of ownership of PC and the ICT use in geography lessons are showed in the table 2. As it is possible to see the influence of age was significant on all categories, and the statistically significant influence was found out at variable "ICT use on geography lessons". This variable had got the statistically significant influence on the categories "Geography as a school subject" and "Geography in practice". In the first category Tukey post-hoc test showed the statistically significant differences between groups "once a month" and "once a week" $(p<0.05)$ and between groups "once a month" and "never" $(\mathrm{p}<0.01)$. 
PROBLEMS

OF EDUCATION

IN THE $21^{\text {st }}$ CENTURY

Volume 50, 2012

Table 2. Values of analysis of covariance.

\begin{tabular}{|c|c|c|c|}
\hline Category & Age & Ownership of PC & $\begin{array}{c}\text { ICT use on geography } \\
\text { lessons }\end{array}$ \\
\hline $\begin{array}{c}\text { Geography as a school } \\
\text { subject }\end{array}$ & $34.99^{\star * \star}$ & 0.09 & $7.42^{\star \star *}$ \\
\hline Geography in everyday life & $15.85^{\star \star *}$ & 1.13 & 0.09 \\
\hline Map use in geography & $10.47^{\star *}$ & 0.00 & 0.23 \\
\hline Geography in practice & $10.69^{* *}$ & 0.34 & $3.19^{*}$ \\
\hline
\end{tabular}

The figure 2 showed the distribution of score in the categories with respect to ownership of PC. Nearly in all categories achieved the owners of PC more positive attitudes toward geography in comparison with non-owners. Only in the third category "Map use in geography" the score was identical.

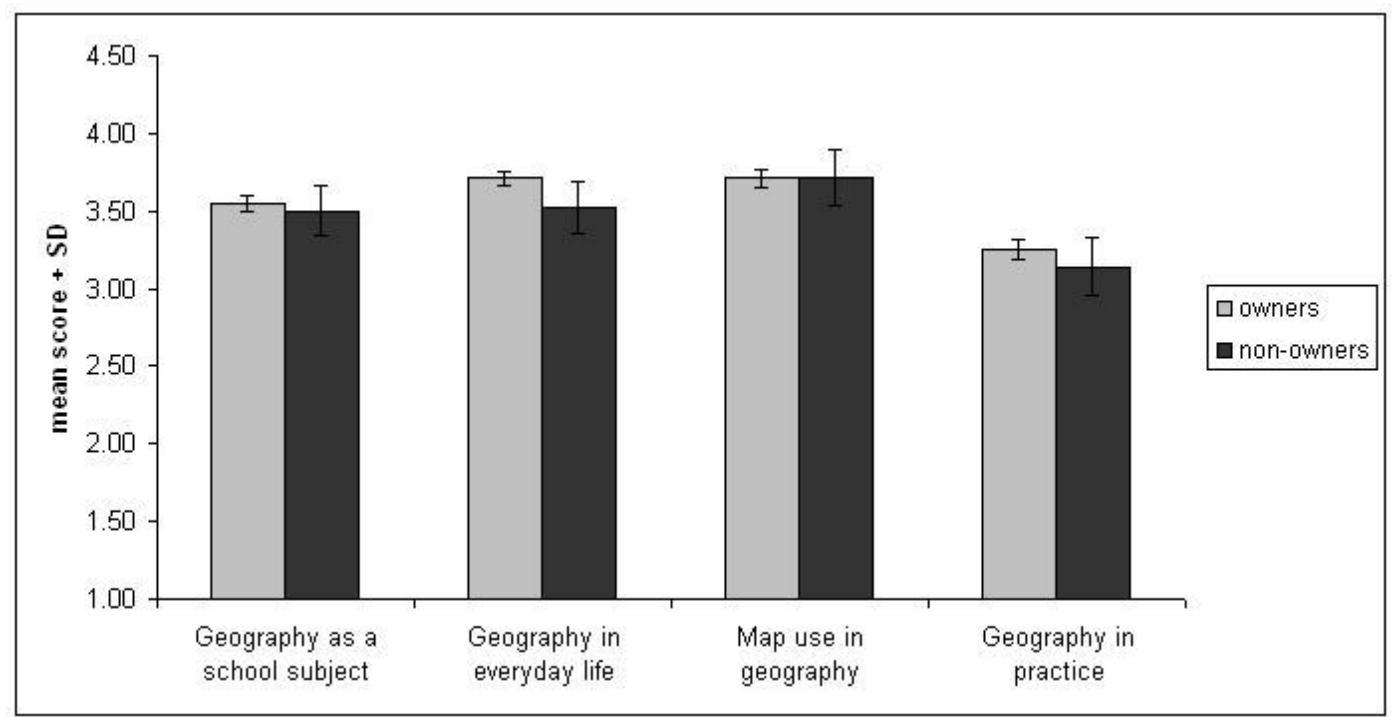

Figure 2: The distribution of score in the categories with the respect to ownership of PC.

The figure 3 showed the distribution of score in the categories with respect to ICT use in geography lessons. In the first and fourth category the highest score achieved pupils, who used the ICT once a month on the geography lessons and the lowest score achieved pupils, who never used ICT on the geography lessons. In the second category "Geography in everyday life" the pupils, who used ICT on geography lessons once a week achieved the highest score. In the third category "Map use in geography" is possible to see interesting result, the pupils, who never used ICT on the geography lessons achieved the highest score and pupils, who used ICT once a week achieved the lowest score. 


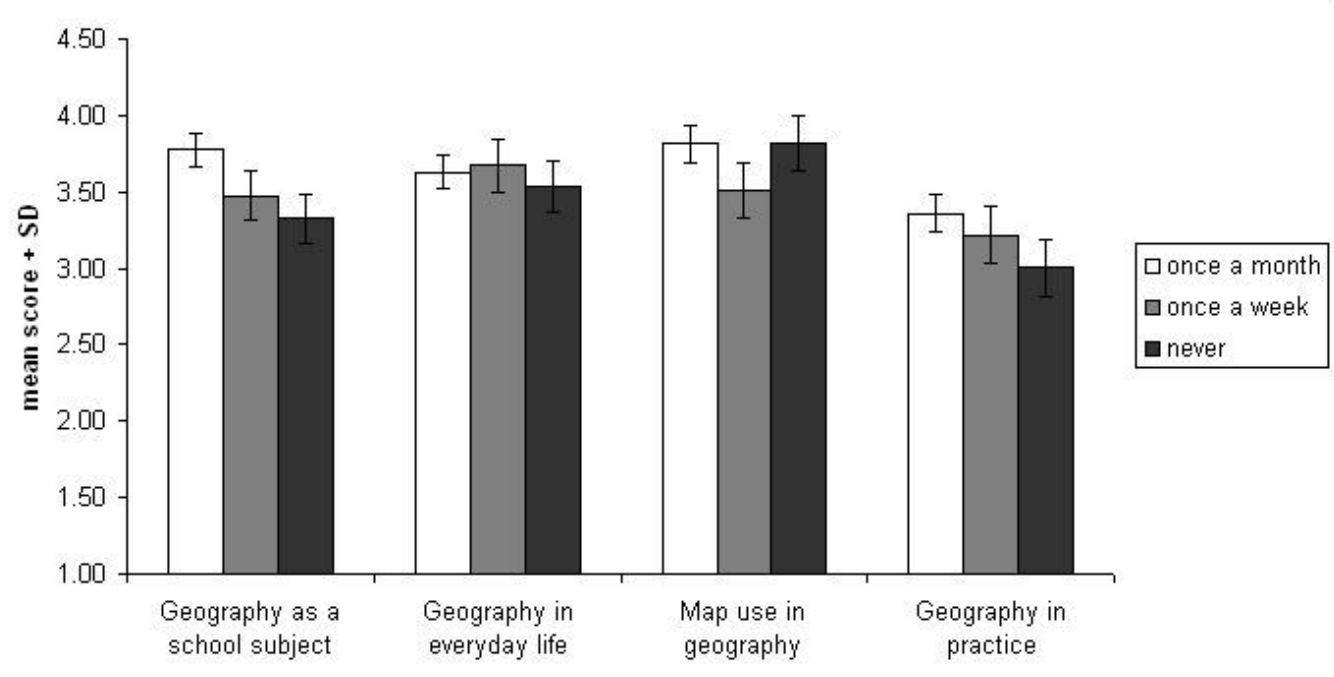

Figure 3: The distribution of score in the categories with the respect to ICT use in the geography lessons.

\section{Discussion}

The study was focused on the finding out the influence of PC ownership and ICT use in geography lessons on the attitudes toward geography. The ownership of PC had not got the influence on the attitudes toward geography. This fact is caused by the different using of PC in the home environment as on the using due to geographical problematic. By the analyzing of the category there was found out interesting results, the identical score in the category "Map use in geography" for owner and also for non-owners of PC. On the basis of this fact it is possible to say, that ownership of PC had not got any influence on the map using.

The influence of ICT use on the geography lessons was significant. The teachers, who used ICT on this lessons confirmed, the ICT is primarily used on the activities regarding to geography. So, this activity had got positive effect on the attitudes toward geography. But there is possible to notice the interesting effect. When the ICT is used once a week, probably there is an overloading of pupils by information and they did not see the influence of ICT on geography so positive, when the ICT is used in minor level (once a month). Next, there is possible to observe, the ICT had got positive influence, when pupils see the connection with ICT and geography as school subject and also, when there pupils see the connection between ICT and impact on geography on practical life. But the map use is not in connection with ICT, there it seems, the ICT had got relatively reversely effect on the map use. There is maybe one contradictory explanation, if teachers work with GIS or with similar technology in their lessons; it could have negative effect on the attitudes toward geography. Maybe for pupils is the using of this technology too demanding and it had got negative effect on their attitudes. It is in the contradiction with all studies regarding to GIS (e.g. Kaya, 2011). From the above mentioned facts the use of ICT provides to support and develop students' scientific reasoning and analytic skills. Some studies show, the positive influence of using ICT during teaching process on better understanding of targeted topics and concepts (Stern, Barnes, Shauli, 2008).

There is too many ways, how the research in this area could be move forward. The question about the effect of the using GIS in the teaching of geography is very actual in the conditions of Czech Republic. There is no the study, which could say more about the situation of the GIS implementation in the lower secondary schools. Also, in this study it is introduced 
PROBLEMS

OF EDUCATION

IN THE $21^{\text {st }}$ CENTURY

Volume 50, 2012

30 the influence of ICT on the attitudes toward geography among lower secondary school pupils, the interesting findings could be found out among high school students and also among college students. There is also possibility to find out an influence of the classical variables (gender, residence, year of study, achievement of students) with the combination of ICT using on the attitudes toward geography.

\section{Conclusion}

The study belongs among the first studies, which is investigated the ownership of PC and ICT use in geography lessons on the attitudes toward geography in the conditions of the Czech Republic. There is offered the research tool, which could be used by other researchers from the other countries on the investigation of similar problematic. On the basis of our research is possible to observe positive impact of ICT using on the attitudes toward geography, but in the reasonable level. The excessive using of the ICT could lead toward reversed effect. As authors, we hope, that our research at least partially fill the gap in this area of investigation.

\section{References}

Baker, T. R., White, S. H. (2003). The effects of G.I.S. on students' attitudes, selfefficacy, and achievement in middle school science classrooms. Journal of Geography, 102 (6), 243-254.

Demirci, A. (2008). Evaluating the Implementation and Effectiveness of GIS-Based Application in Secondary School Geography Lessons. American Journal of Applied Sciences, 5 (3), 169-178.

Hubelova, D. (2010). Application of Information and Communication Technologies (ICT) in Geography Lessons. Pedagogika, 99, 89-94.

Kaya, H. (2011). Primary 6th Grade Students' Attitudes Towards the Social Studies Lesson Aided with Geographic Information Systems (GIS): Karabük Case. Middle East Journal of Scientific Research, 7 (3), 401-406.

Kerski, J. J. (2001). A national assessment of GISin American high schools. International Research in Geographical and Environmental Education, 10 (1), 72-84.

Kubiatko, M., Usak, M.,Yilmaz, K, Tasar, F. H. (2010). A crossnational study of Czech and Turkish university students attitudes towards ICT used in science subjects. Journal of Baltic Science Education, 9 (2), 119-134.

Lemberg, D., Stoltman, J. (1999). Geography teaching and the new technologies: opportunities and challenges. Journal of Education, 181 (3), 63-76.

Morgan, J., Tidmarsh, C. (2004). Reconceptualising ICT in geography teaching. Education, Communication \& Information, 4 (1), 177-192.

Rich, D. C., Robinson, G., Bednarz, R. S. (2000). Collaboration and the successful use of information and communications technologies in teaching and learning geography in higher education. Journal of Geography in Higher Education, 24 (2), 263-270.

Stern, L., Barnes, N., Shauli, S. (2008). The effect of a computerized simulation on middle school students' understanding of the kinetic molecular theory. Journal of Science Education and Technology, 17 (4), 305-315.

Taylor, L., Group, B. C. (2003). Effective use of ICT in geography coursework. Teaching Geography, 28 (2), 94-96.

West, B. (1999). Geographical literacy and the role of GIS. New Zealand Journal of Geography, 107, 24-25. 
Milan KUBIATKO, Katerina MRAZKOVA. The Influence of Ownership and Using of PC on the Attitudes toward Geography

\begin{tabular}{|c|c|}
\hline & $\begin{array}{l}\text { PROBLEMS } \\
\text { OF EDUCATION } \\
\text { IN THE } 21^{\text {st }} \text { CENTURY } \\
\text { Volume 50, } 2012\end{array}$ \\
\hline Advised by Laima Railiene, University of Siauliai, Lithuania & 31 \\
\hline
\end{tabular}

Received: October 22, 2012

Accepted: December 05, 2012

Milan Kubiatko

PhD., Assistant Professor, Institute for Research in School Education, Faculty of Education, Masaryk University, Porici 31, 60300 Brno, Czech Republic. E-mail: mkubiatko@gmail.com

Website: http://www.kubiatko.eu/

Katerina Mrazkova

PhD Student, Department of Geography, Faculty of Education, Masaryk University, Porici 7, 60300 Brno, Czech Republic.

E-mail: mrazkovak@gmail.com 